\title{
D layers, interests and public 1 policies in relation to tourist rental housing in Spain (2010-2019). Complexity and multiple conflicts
}

Players, interests and public policies

\author{
Auxiliadora Comendador-Sánchez, \\ Universidad de Sevilla, Sevilla, Spain \\ Enrique Santos-Pavón, \\ Universidad de Sevilla, Sevilla, Spain \\ Javier Hernández-Ramírez, \\ Universidad de Sevilla, Sevilla, Spain
}

\begin{abstract}
Purpose: The purpose of this paper is to shed light on the general scenario resulting from the emergence and expansion of tourist rental housing in Spain during the period 2010-2019.

Design/methodology/approach: The approach adopted is qualitative and focusses on identifying the range of players involved in the phenomenon and their varying interests; it also analyses the differing roles played by public authorities through the adoption of regulatory tools and the responses to these.

Results: This paper shows the existence of a diversity of positions among the various players involved in the phenomenon, as well as divergent responses from public authorities to their demands. This reveals the existence of a complex, heterogeneous scenario characterized by tension between the players; a situation that has not been satisfactorily resolved by the regulatory tools adopted, in the light of the conflicts observed.

Originality/significance: The main significance of the work lies in its contribution to the general understanding of the phenomenon of dwellings for tourist use in Spain from a broad, nationwide perspective, which seeks to correct the usual local and partial approaches.
\end{abstract}

Limitations of the research: The timescale of the study, the decade 2010-2019, delimits the theoretical framework, the analyses carried out and the conclusions obtained to this period.

Keywords: Dwellings for tourist use, tourist rental housing, players involved, regulatory tools, multiple conflicts

Paper type: Research paper

(C) Auxiliadora Comendador-Sánchez, Enrique Santos-Pavón and Javier Harnández-Ramírez. Published in Journal of Tourism Analysis: Revista de Análisis Turístico. This article is published under the Creative Commons Attribution (CC BY 4.0) license. Anyone may reproduce, distribute, translate and create derivative works of this article (for both commercial and non-commercial purposes), subject to full attribution to the original publication and authors. The full terms of this license may be seen at http://creativecommons.org/licences/by/4.0/legalcode

Journal of Tourism Analysis: Revista de Anólisis Turístico Vol. 28 No. 1, Año 2021 pp. $1-21$ 
JTA

28.1

\section{Introduction: the touristification of housing in cities}

The phenomenon of the proliferation of tourist rental housing cannot be separated from the more general process of transition from Fordism to a regime of flexible accumulation (Lash and Urry, 1987; Ioannides and Debbage, 1997; Delgado, 1998). In the tourism sector, this transition has meant a shift from a vertically organised model in which large corporations and companies controlled most of the business, to one in which new players involved in the production and marketing of tourism goods and services have emerged and proliferated on a global scale (Shaw and Williams, 2004).

The combination of two factors has been crucial to the success of this transition: the development of information technologies and the desire of tourists for new experiences (Richards, 2016). In just a few years, multiple digital platforms have burgeoned to compete with the business model of traditional companies and to act as intermediaries between consumers and tourism service providers within the, somewhat ambiguously named, collaborative economy (sharing economy or peer to peer) (Bakker and TwiningWard, 2018).

This new phenomenon of promoting and marketing goods and services between individuals through digital platforms - called uberization (Bani, 2017) or airbnbification (Richards, 2016) - is here to stay. Virtual intermediaries are intervening in practically all branches of tourism activity (transport, accommodation, activities, information), noticeably increasing competition and innovation by offering new services, such as the so-called "experiences" marketed by Airbnb. This dynamic is triggering a surge in new companies that are expanding the supply of complementary services aimed mainly at users of tourist accommodation (lockers, laundromats, car parks, bureaux de change, personalised tours, health care, courses and seminars on local customs and cultural practices, rental of electric and portable vehicles such as bicycles, mopeds, scooters, overboards, unicycles and an ever-increasing list.) (Moreno-Izquierdo et al., 2016). All of this favours the emergence of a new class of entrepreneur providing innovative tourism services, some of which could be classified as part of the so-called creative economy (Richards, 2018) and others considered ancillary tourism industries.

Therefore, this transformation is not only quantitative but qualitative: digital platforms are changing the very nature of the tourism business, since they connect all manner of providers and entrepreneurs with tourists and consumers and encourage the development of new activities and services. In fact, one of the main keys to the success and growth of this new business model is its capacity to facilitate more direct access of the visitor to the socio-cultural reality of the destination he or she is visiting, since these new services are enlarging the field of tourist expenditure to more intimate, local and behind-the-scenes ambits (houses, parking lots, neighbourhoods, etc.). The possibility of closer contact with the destination immerses the visitor in its everyday life, allowing them to have an authentic experience, as if they were a local, thus satisfying one of the most sought-after objectives of many tourists (Urry, 1999; Wang, 1999; Judd, 2003; Richards, 2017). This is what Quaglieri and Russo (2010) cleverly denominate with the oxymoron: "extraordinary everydayness".

Dwellings for tourist use are part of this general phenomenon. According to various studies (Cócola-Gant, 2016; Alfonso, 2016), their development would not have been the same without the intermediary role of digital platforms, which have substantially increased the number of beds available on demand and mobilized investors and entrepreneurs in the real estate and tourism businesses. Hand in hand with the Airbnb phenomenon and the enormous growth it has experienced since its beginnings in 2008 as a community-based collaboration (according to its own definition), other peer-topeer platforms have been emerging onto the international market until, at the end of the last decade, they offered 22 million homes for tourist use (Transparent Media Consulting, 2018), enjoying continuous growth that has been evolving at a faster rate than traditional tourist accommodation (hotels and similar establishments). 
In Spain, the trend has also been towards growth until 2019, when a relative decline can be seen, which is attributed by the sector's entrepreneurs to greater regulation by the authorities (Graph 1).

Graph 1. Number of tourist rental housing places in Spain (2009-2019)

Players, interests and public policies

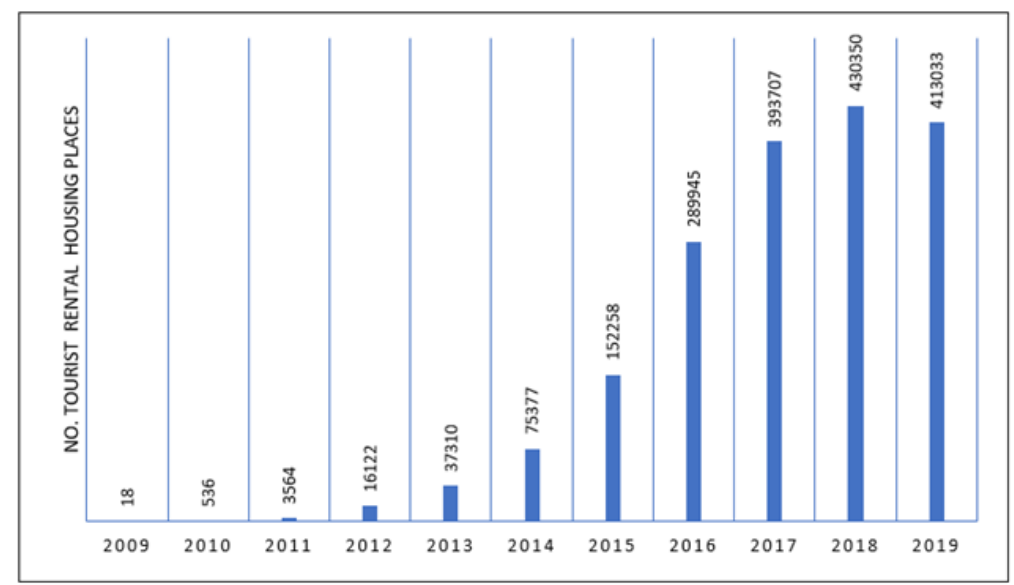

Source: Exceltur (2020). Compiled by authors

The growth in tourist rental housing in urban holiday destinations has directly affected the functioning of the sector, modifying business models, but it has also caused an abrupt disruption of the housing market. This is due to the emergence of new players who are profiting from this new form of temporary rental. This is because the profit margin they provide is higher than that generated by long term rentals and, furthermore, maintenance costs are lower than those of hotel accommodation (Exceltur, 2015).

This new scenario is generating antagonism and various social conflicts, both with the traditional tourism industry, which is facing new competitors in a business that until recently was dominated by them, and with the residents of the areas where the phenomenon is taking place, who are affected by a reduction in the supply of housing for long-term rental and a corresponding increase in its price (Cócola-Gant, 2016; Jover et al., 2018; Cañada and Murray, 2019).

The real estate market is undergoing a transformation, since the large profits generated by the tourist rental housing business have a direct impact on the areas where the homes are located. In these areas we are witnessing the development of competition and the transformation of the traditional residential function of housing understood as an asset for long-term use and mainly oriented to the local population into a different model in which housing is converted into a tourist commodity, with temporary accommodation for the visiting population taking precedent. This touristification of housing is also reorienting the functions and the socio-cultural character of urban space, since it reduces the availability of land and buildings for residential use, causing a general increase in the cost of housing. This process favours tourist gentrification, i.e. the transformation of the local neighbourhood into one of tourist use which, due to its transient and temporary nature, encourages only ephemeral and superficial contact - which, moreover, is usually only one-off - with the increasingly scarce local population. The result is that the social fabric of the neighbourhoods becomes frayed and they mutate into scenarios where, paradoxically, 
JTA

28.1

local culture is displayed for tourist consumption (Cócola-Gant, 2016; Hernández-Ramírez, 2018).

These developments and conflicts have increased due to the absence or laxity of public policies and legislation aimed at regulating the housing market and the use of dwellings (Rodríguez-Alonso, 2011; Leal and Martínez, 2017). However, in recent years public authorities at different levels have adopted legal provisions that seek to regulate this scenario of multiple conflicts, either by facilitating the expansion of housing for tourist use or, conversely, by trying to neutralize its negative effects on the most impacted social and business sectors. Such regulation is not exclusive to the situation in Spain, but has also been adopted in many of the most tourist-oriented cities in Europe, such as Milan, Amsterdam, Paris or London (Blanco et al., 2017).

In short, the phenomenon of dwellings for tourist use is a complex scenario that poses many challenges for the future. The variety of players that intervene, the disparity of interests that come into play, the extent and scope of the conflicts generated by this activity and the varying roles played by public authorities create an unstable general framework of multiple conflicts.

The noticeable impact on life in cities and the conflicting interests of the different players involved in this phenomenon have led to considerable public debate, as well as to an abundant production of literature that approaches this reality from different disciplines and scientific currents (Armas et al, 2014; Hiernaux and González, 2014; Cuscó and Font, 2015; Guillén, 2015; De la Encarnación, 2016; Miralles and Villar, 2016; González, 2017; Herrero, 2017; Roca, 2017; Fuentes-Lojo, 2018; Fuentes-Lojo et al.).

This paper aims to contribute to the understanding of the phenomenon of tourist rental housing in Spain over the last decade, framing it in the general context of the global expansion of tourism within the post-Fordism accumulation regime. In contrast to the numerous approaches to the phenomenon from a local perspective undertaken to date, this work offers a nationwide overview. This broad angle makes it possible to overcome the limitations of very localised approaches and to understand the diversity of responses of the sectors involved, as well as to ascertain the similarities and differences in the various public authorities' treatment of the phenomenon within their spheres of competence and geographic scope.

This multiscale approach is complemented by a perspective that addresses tourist rental housing as a multi-pronged phenomenon. As a consequence of this, the analysis adopts a holistic view that stems from the observation of its complex, multi-sectoral and multi-conflict nature of actors competing in a shifting interplay of forces to reach a position of advantage within the tourism market.

In accordance with this theoretical approach, this paper sets out three fundamental objectives:

1. To identify the players involved in the phenomenon of the expansion of the dwellings for tourist use, to highlight their different interests and to determine the particular problem that affects each one of them.

2. To recapitulate and compare the normative and regulatory tools adopted by regional and municipal authorities on the matter.

3. Analyse the reaction and response of the different players involved to the regulatory tools adopted. 


\section{Methodology and sources of information}

In accordance with its objectives, this paper analyses the phenomenon of housing for tourist use in Spain during the decade 2010-2019. The choice of this timeframe is warranted because it covers the period of greatest growth in the advent of this type of housing, as well as the period of greatest regulatory activity on this matter. Prior to these dates, dwellings for tourist use were predominantly located on the Spanish coast, in response to the demand for so-called residential tourism (Santos-Pavón and Fernández-Tabales, 2010). Since 2010 a new business model of tourist rental dwellings, which is the subject of this paper, has developed rapidly. This model displays three novel characteristics: firstly, the participation of digital intermediary platforms; secondly, the predominant location of dwellings in urban holiday destinations and, finally, their non-seasonal nature. The study adopts a qualitative methodology that takes four types of documents as sources of information:

Firstly, a large number of scientific articles and technical documents which address the phenomenon of housing for tourist use from different perspectives and interests (social, territorial, cultural, legal and economic) have been reviewed. This has yielded a more in-depth understanding of the complexity of the phenomenon, its many ramifications and nuances, the various players involved, the problems and conflicts generated in the holiday destinations, etc.

Secondly, a detailed review and comparative analysis has been carried out of the different regulatory tools, adopted by both regional and local authorities, to regulate dwellings for tourist use within their sphere of competence. This documentation has made it possible to determine to what extent a response is being given to the problems and complaints affecting each of the players.

Thirdly, extensive and varied newspaper archive material has been gathered, providing very up-to-date information on facts, circumstances and vicissitudes that are not usually dealt with in scientific literature, but which provide very interesting information on the interests at stake, as well as on the tensions and alliances between the different players, from a diachronic perspective.

Fourthly, a fundamental part of our research has been the analysis of the legal appeals filed up to 2019 by certain players against some of the regulatory tools adopted by the authorities and the judicial rulings these are receiving. This information is essential to better understand the interests and demands of the different sectors involved in the phenomenon of tourist rental housing.

In view of the need to collate the large amount of information on the regulatory tools adopted and the legal actions taken against them, in a clear, orderly and succinct manner, a series of tables have been drawn up to facilitate understanding and comparison of all the documents analysed. At the same time, the underlying discourses -explicit and implicit- in each of the documents have been compared and analysed, identifying and delving into the interests and objectives of the stakeholders who formulate them.

\section{Analysis and results: the players involved in the phenomenon of tourist rental housing}

The arrival of tourist rental housing in urban holiday destinations is a relatively recent and complex phenomenon that clearly highlights two main issues that have diverse repercussions and offer different readings, depending on the interests of the various players involved (Román, 2018). These two main issues are:

- The rapid and often uncontrolled growth in the number of tourist accommodation beds in certain areas of cities. 
JTA

28.1

- The change of a good number of dwellings from residential to tourist use, together with the transformation, in favour of tourism, of public space and the commercial fabric of the areas affected.

These transformations, and their consequences, have been gradually addressed by the authorities through the development of specific regulation of the sector.

For decades, tourist rental housing in Spain was legally covered by successive urban leasing laws, within the generic category of temporary rental. The situation changed in 2013 with the approval of the Law 4/2013, of 4 June: measures to promote and increase flexibility in the rental housing market, which considered temporary leasing for tourist purposes to be a tourist business activity and, therefore, within the ambit of the regulations of that sector adopted by the regional authorities.

As a result, all of the regional authorities already have regulations governing dwellings for tourist use (Table 1), although their criteria differ in the aspects they regulate (Del Busto et al., 2019), specifically: the obligatory requirements of customer assistance and quality; the requirements of licensing the activity; decisions related to tourist inspection; and the sanctions for breach of obligations (commercial, social harmony or environmental).

Additionally, in certain municipalities where the phenomenon has expanded substantially, various urban planning tools have been adopted to regulate tourist housing (revision of land-use plans, formulation of special plans, approval of municipal ordinances), further contributing to the complexity and diversity of the regulatory treatment of the phenomenon.

Through the regulation of tourist rental housing, the authorities have sought to organize the sector and provide solutions to some of the issues caused by this activity, which impacts the diversity of players in different ways (Table 2).

These stakeholders (Freeman, 1984) comprise a heterogeneous network of groups with specific and often conflicting interests that, to varying degrees, participate in the phenomenon of tourist rental housing, either by influencing its expansion, intervening in its regulation or being affected by its development. As a whole, this diversity of players constitutes a system that is dynamic and subject to tensions, conflicts, negotiations and alliances, since it is forged by the interdependence and interaction of each and every one of the interested parties.

In the field of tourism, the specialized literature defines four groups of stakeholders: the public sector (organizations and authorities at all levels); the private sector (companies directly and indirectly involved in the activity); tourists (of different types); and the local neighbourhood (both residents in tourist areas and from other areas) (Jamal and Getz 1995; Sautter and Leisen, 1999; Liu, 2003; Bramwell, 2011; Gomez \& Martín, 2015).

For the analysis of the specific case of tourist rental housing, this study applies the theory of stakeholders (Presenza \& Cipollina, 2010). This work identifies seven welldefined sectors, namely: digital intermediary platforms, owners of dwellings for tourist use, tourists who use this type of accommodation, residents of the areas affected by the phenomenon, the hotel sector, travel agencies and political players.

Each of the players involved has their own peculiarities and there are also significant internal differences in terms of the degree of organization and structure. Some of them form real lobbies or pressure groups thanks to their considerable capacity to influence decision-making processes. However, other sectors are diffusely organized and achieve less impact and public notoriety, so their influence is more limited.

These stakeholders are identified below in order to establish the position of each them with regard to the problems arising and to examine the impact of the regulations adopted, based on the analysis of their discourse, demands and behaviour. 


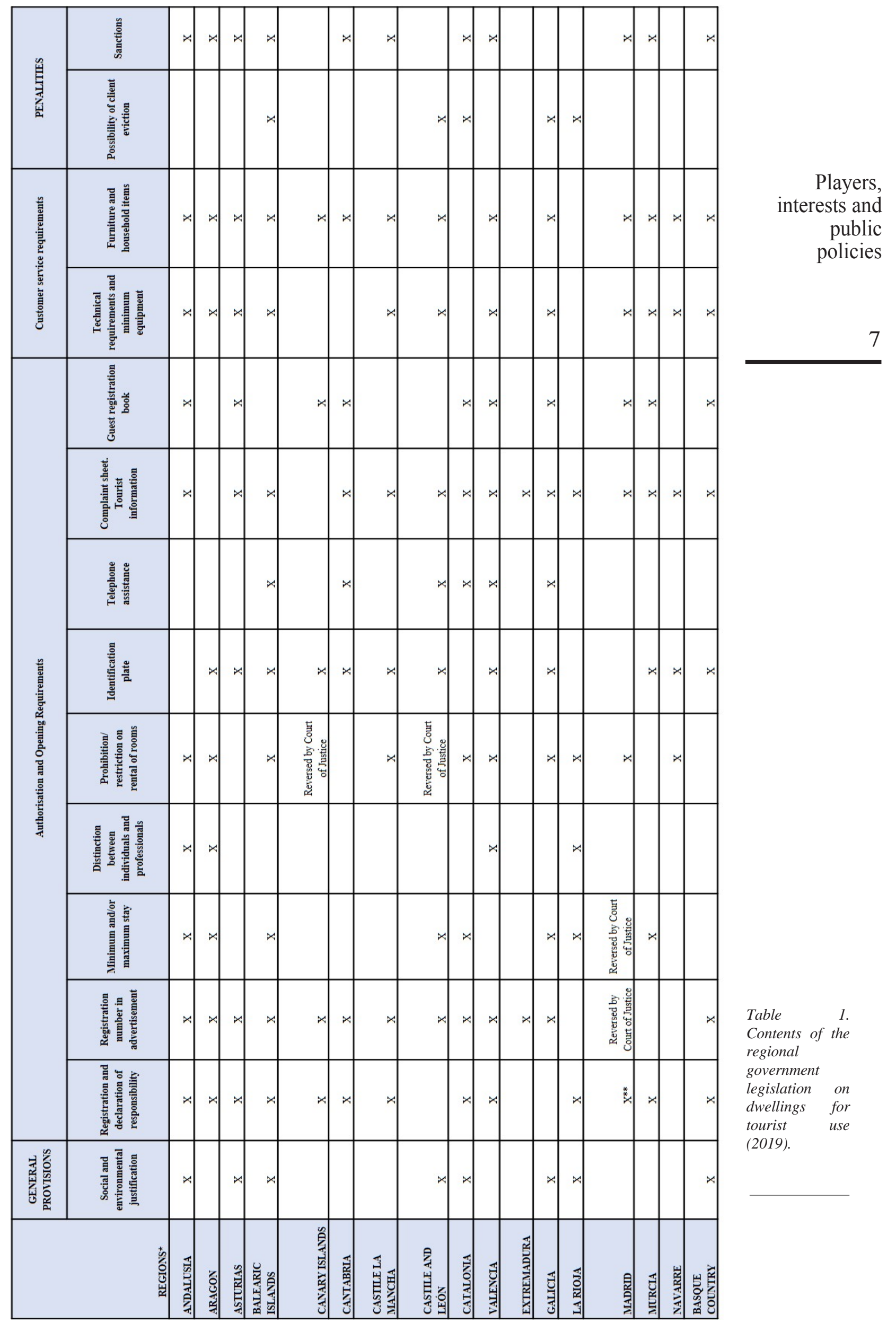




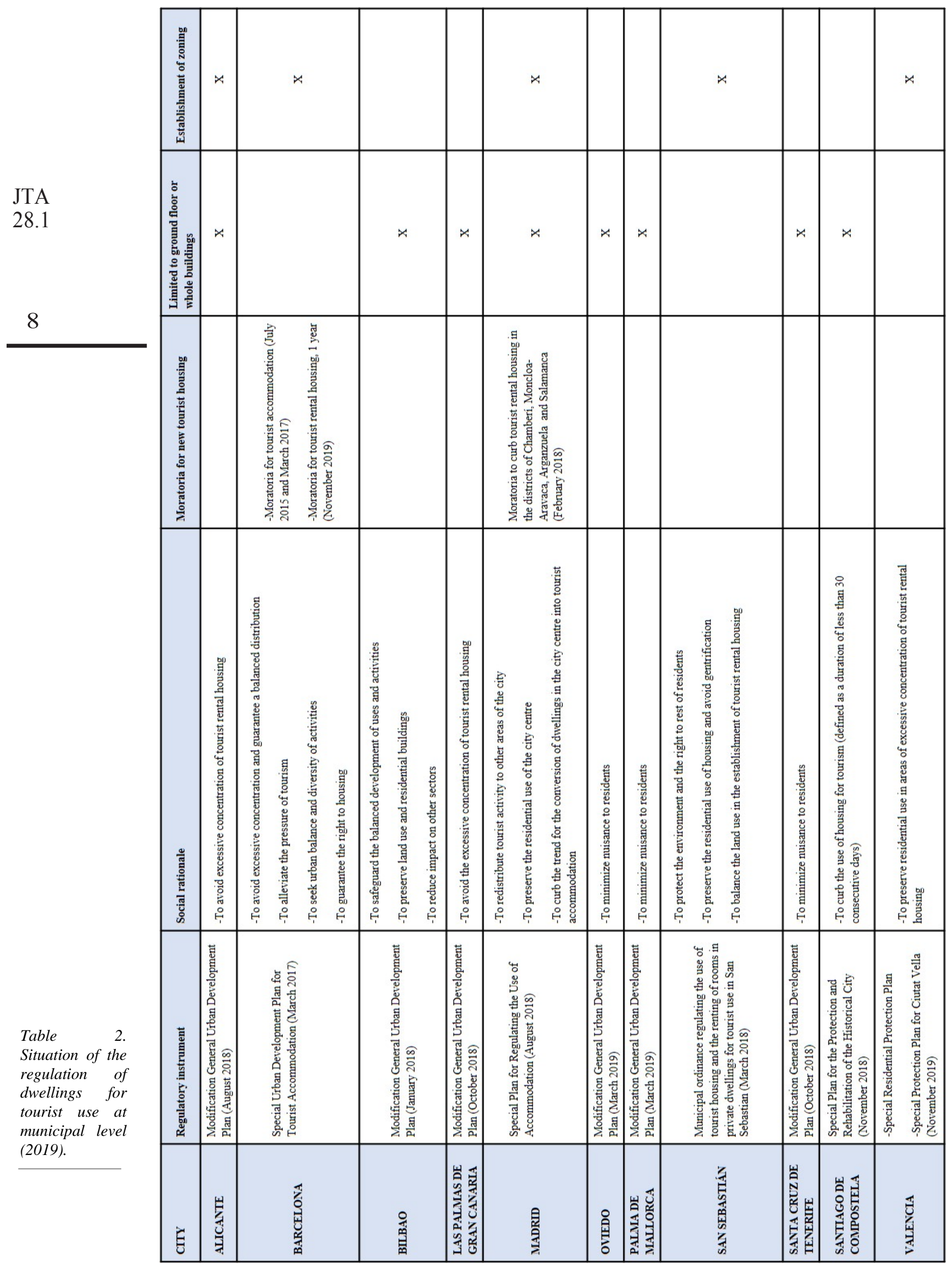




\subsection{Digital intermediary platforms}

Digital platforms that provide tourist accommodation in homes have played a decisive role in the enormous expansion of the phenomenon over the last decade (Oskam and Boswijk, 2016). Their arrival in the tourism sector has been a disruptive innovation (Díaz et al., 2014; Guttentag, 2015) that has transformed homeowners into hosts, temporary tenants into guests, dwellings into tourist accommodation and local residents into the permanent neighbours of new incidental neighbours.

These platforms, together with the homeowners, have perhaps benefited the most from the emergence of this phenomenon, since in addition to obtaining financial profit as a result of their work as intermediaries, they benefit from specific tax conditions that significantly reduce their taxation (they pay taxes through their parent companies based in countries that grant them tax breaks, as is the case of Airbnb in Ireland) (Recio, 2016). This position of advantage is criticised by other players (travel agencies, for example), in view of the scant regulation of these platforms' activity in Spain, with the exception of the general legislation applicable to e-commerce and, more specifically, Royal Decree 1070/17, which obliges them to provide the details, for tax purposes (Agencia Tributaria, 2018), of the homeowners who use them.

The platforms, as a response to the pressure exerted by other agents (hoteliers and, sometimes, the general public), are reacting by applying certain self-regulation measures, such as requiring that the tourist homes on offer display their official registration number (the case of Airbnb and HomeAway). Apart from the small number of provisions and measures mentioned, the intermediary platforms are the player which has profited considerably from the significant growth in the supply of this accommodation and is minimally affected by new regulations that practically ignore them while focusing their attention on other players and processes in the sector.

\subsection{Users of tourist accommodation}

The growing number of travellers who have chosen to stay in tourist rental housing in the last decade has been a major driving force in the expansion of this type of accommodation in Spain. As a result, in 2018, there were nearly 8 million users of this type of accommodation, which is double the figure of a decade earlier (Esade, 2015; Instituto Multidisciplinar de la Empresa, 2019).

According to data provided by Exceltur, based on a survey conducted in Spain among more than 2,200 users of tourist rental housing of four different nationalities, most users indicated that the price, independence and spaciousness of the accommodation were decisive factors when choosing. However, the results of the survey also indicated an interest among users in getting involved in the life of the local area, which is in keeping with the profile of a younger and more adventurous type of tourist, as opposed to those who choose hotel accommodation (Exceltur, 2015, pp. 31-32).

Nonetheless, it should not be forgotten that tourists in general, including those staying in tourist rental housing, form a heterogeneous group characterised by a diversity of motivations and expectations, which explains why they do not constitute an organised group of stakeholders who collectively defend their common interests. When tourists give their views, complain or make demands, they generally do so in a personal capacity through opinions and evaluations on the platforms or through legal complaint procedures. Nevertheless, the Spanish Consumers and Users Organisation's (OCU) declaration rejecting the tourist housing regulations of the City Council and the regional government of Madrid, should be highlighted as exceptional
Players, interests and public policies 
The OCU considers these regulations to be "restrictive" and "disproportionate", and to

"hinder access to a wide range of legitimate services, which would ensure free choice for consumers and the protection of their rights" (OCU, 2019). Conversely, in 2018 the FACUA-Consumers in Action organization called for tourist rental housing intermediary platforms to be made accountable to the users when problems arise in the provision of the services contracted, thereby defending the rights of the consumers (Europa Press, 2018).

In any event, these are statements from general consumer organisations, and there is no record of any legal action by specific groups or associations of users of this type of accommodation with regard to the local and regional regulations adopted on this matter.

\subsection{Owners of tourist rental housing}

The owners of tourist rental housing are the principal players within the context being analysed, both because of their responsibility in the development of this activity and as a party affected by the regional and/or municipal regulation of this type of accommodation.

However, it should be noted that owners do not form a homogeneous group, but rather they range from small local owners for whom the renting of rooms or a second home is a complement to their domestic economy (help with mortgage payments, obtaining extra income, etc.), to large companies specializing in real estate investments (Socimis) that have numerous dwellings devoted to tourist rental. There is not an even balance between the two within the sector: large owners and multi-managers dominate the market (Sánchez-Uzábal and Rey-Mazón, 2019).

There is a wide variety of cases between one extreme and the other but they all have in common the business nature of their activity and the financial profit derived from the change of use, from residential to tourist, of the properties. In this context, the interests of the owners have usually been aligned in favour of the liberalisation of the business and minimum regulation by the authorities. This explains the lodging of various legal appeals against several of the regulatory provisions adopted by regional authorities and local councils on the matter, either through the main associations of tourist property owners (Fevitur, Aviturga, Apartsur or Madrid Aloja), or through the initiative of the National Commission for Markets and Competition (CNMC), a public body that is highly critical of the regulatory measures it considers to be obstacles to free competition in the tourism sector.

Hence, there have been appeals against the decrees issued by the regional authorities of Andalusia, the Canary Islands, Castile and Leon, Galicia and Madrid, as well as various municipal regulations such as those of Bilbao, San Sebastian and Madrid, in each case the argument being that the requirements demanded of tourist rental housing are excessive and disparate, in addition to violating market freedom and free competition (Tables 3 and 4). In this respect, both the CNMC and the owners' associations base their legal appeals on European Directive 2006/123/EC regarding services in the internal market and on Law 20/2013, of 9 December, regarding the guarantee of market unity. 


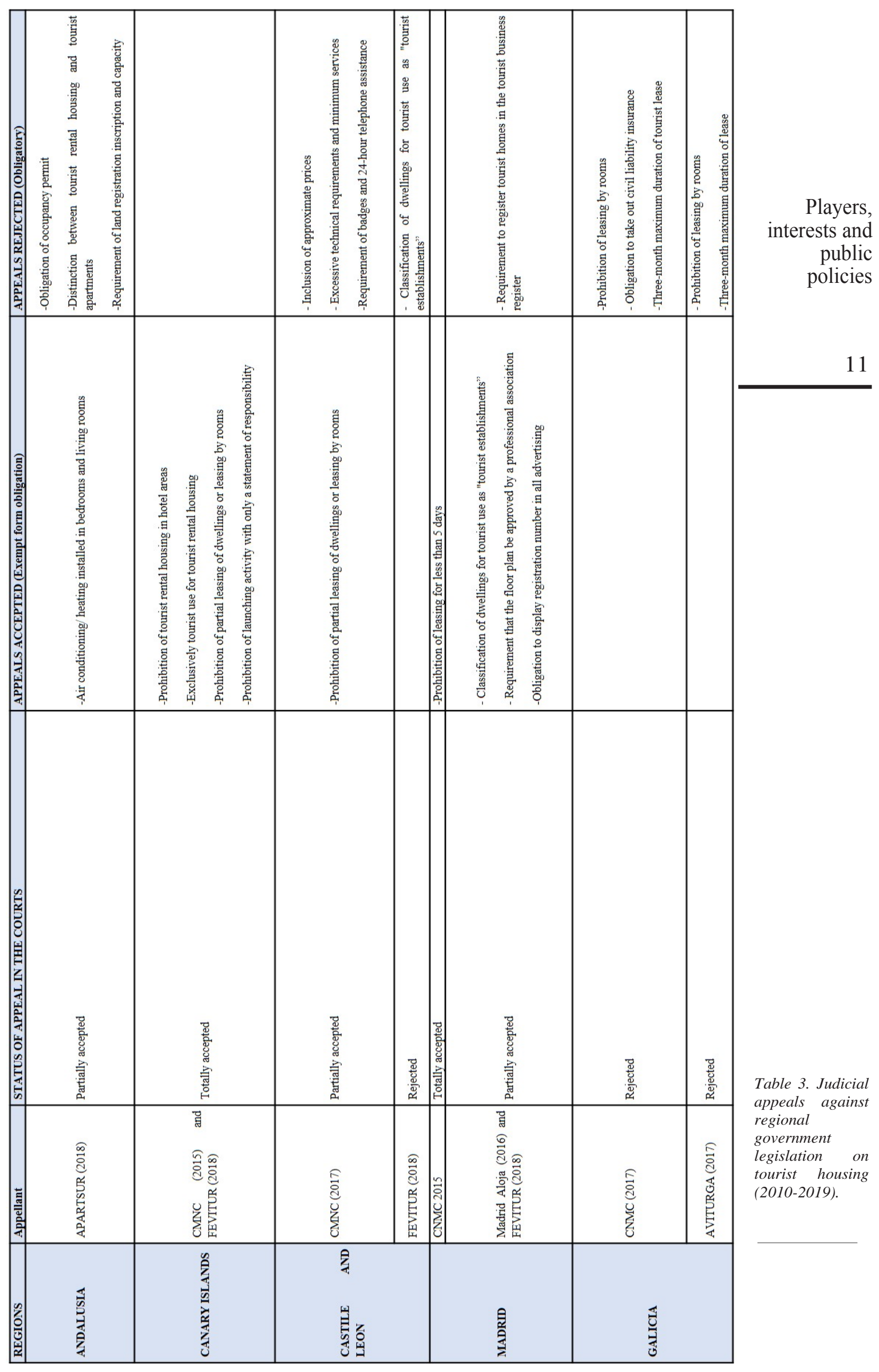


JTA

28.1

12

Table 4. Main legal appeals against the municipal regulation of tourist housing (2010-2019).

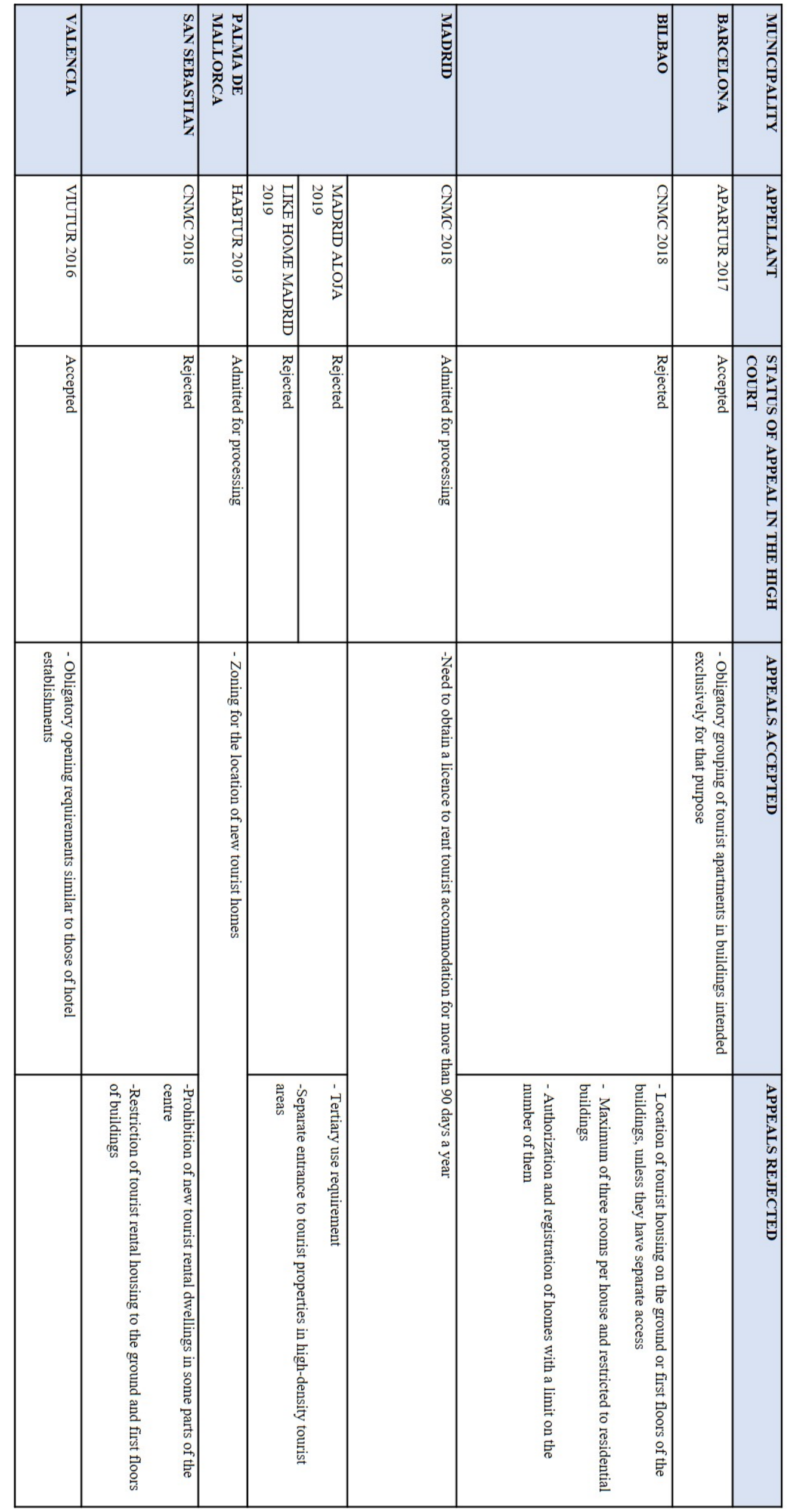


The court rulings on these appeals, when they have occurred, have generally been to recognise that there are excessive requirements for the licensing of tourist rental housing or that the demands regarding customer service are disproportionate. On the other hand, when appeals have been dismissed, this usually reflects the consideration that the obligations imposed by the regulations serve the general interest or the rights of the various players affected by the activity (residents and neighbours, hotels, etc.). However, it should also be noted that the decisions of the courts suffer from a lack of consistency in their criteria and interpretations, which sometimes results in contradictory rulings (Tables 3 and 4).

Players, interests and public policies

\subsection{Residents of areas where there is a proliferation of tourist accommodation}

The residents of areas where there is an abundance of tourist housing are one of the sectors most affected by the advent of this phenomenon. These are the residents of the historical centres and their surrounding neighbourhoods, where the bulk of the city's cultural heritage is usually located and which have the greatest official status and social recognition, as well as being the area most sought after by users of tourist rental housing.

The transformation of many dwellings from residential to tourist use generates two types of interconnected problems that directly affect the neighbourhood: on the one hand, those related to the coexistence between residents and tourists (generation of noise, waste, insecurity, overuse of facilities etc.), and on the other hand, the modifications to the urban environment produced by the phenomenon (overcrowding, commodification of public spaces, decline of traditional commerce, increase in rental prices, gentrification, etc.) (Hiernaux and González, 2014; Cuscó and Font, 2015; Cócola-Gant, 2016; Hernández-Ramírez, 2018).

The ill feeling caused by these developments is generating a broad and structured citizens' movement that is spreading through the most tourist-oriented European cities (Milan and Mansilla, 2018), and which is demanding the "right to the city" (Harvey, 2008) and specific solutions to the problems identified (Alba Sud, 2018). However, this discontent has not resulted in legal appeals against the regional or municipal regulations, as can be seen from the information in Tables 3 and 4.

The regional authorities' responses to residents' complaints have varied. As can be seen in Table 1, the regulations barely take any measures to deal with safeguarding the urban environment in which these dwellings are located. However, the problems associated with nuisance caused to residents are usually dealt with, but only through coercive measures (complaints, sanctions, evictions) applied to users and/or owners who violate the rules of peaceful coexistence.

On the other hand, the urban planning regulations adopted by some local councils have been more responsive to residents' demands and complaints (Table 2). The objectives of these regulations and municipal ordinances are mainly to maintain the residential use of housing by trying to avoid the process of tourist gentrification, to minimize the nuisance caused to residents, and to protect the use of public space and amenities. Among the containment measures adopted by municipal governments, the following three stand out (Table 2):

- Application of restrictions in buildings with tourist rental accommodation. For example, in some cities these must be located on the lower floors of buildings, below dwellings for residential use, sometimes even requiring their own, separate entrance (Bilbao, San Sebastian, Palma de Mallorca or Valencia). 
JTA

28.1

14

- City zoning. Areas are established where the expansion of tourist housing is restrained in line with objective criteria such as the number of existing rental dwellings, their density or the increase detected in rental costs. The objective is to rebalance the distribution of their availability within the city, setting limits in some areas and promoting their installation in others (Barcelona).

- Establishment of moratoria. In exceptional situations, temporary deferrals in the granting of new licenses for tourist housing are also used in certain areas of the city (Madrid, Santiago de Compostela or Barcelona).

Along the same lines, Royal Decree Law 7/2019 on urgent measures in the ambit of housing and renting, was adopted nationwide, establishing the possibility of prohibiting the tourist use of housing in those residents' associations in which homeowners vote against it by a ratio of 3:5, no longer requiring unanimity as was previously the case.

\subsection{The hotel sector}

Tourist rental housing has had a considerable impact on the tourist accommodation sector. Among the establishments most affected by the arrival of tourist rental housing are conventional family tourism establishments (two and three star hotels, tourist apartments, hostels), the demand for which has moved in favour of tourist rental housing reaching almost 54\% (Muñoz et al., 2019). This situation has generated concern and given rise to complaints and specific demands, particularly from the hotel subsector.

Different types of tourist accommodation establishments are regulated by the regional authorities through the development of specific regulations, with tourist rental housing being the latest type to arrive on the scene in Spain. Although tourism regulations govern, among other things, the relationship between the authorities and companies and professionals in the sector (Fuentes-Lojo et al., 2018; Ortega, 2018), in the case of tourist rental housing the situation is different because many of the owners are not companies or tourism professionals, so they receive a differentiated treatment adapted to the particular characteristics of this type of accommodation.

This differentiated (or unequal) treatment is described by the hotel subsector as "unfair competition" (Guillén, 2015:102), and as a result there are calls for an alignment of the regulations based on two fundamental principles. Firstly, that the requirements for tourist rental housing be brought into line with those of other accommodation establishments, to avoid situations of inequality between economic actors which offer a similar service: accommodation for tourists. And, secondly, the establishment of a more balanced tax regime for the whole of the tourist accommodation sector is called for, together with the application of a more proactive inspection regime that would allow tourist housing operating in the informal economy to emerge (Ginés, 2018; Vargas, 2019).

The demands made on these issues have not been judicial in nature, but are being formulated as complaints and appeals by the Spanish Confederation of Hotels and Tourist Accommodation and various local hotel business associations, which are disseminating them through the media to broaden their scope and social impact.

For their part, the authorities have not heeded all the complaints raised by the hotel sub-sector. As can be seen in Table 1, none of the regional governments establish categories of tourist rental housing that are equivalent to the rest of accommodation establishments, although they do define a series of opening, habitability and customer service requirements, as well as a system of penalties for non-compliance. However, these requirements are not directly equivalent to those demanded of other tourist accommodation establishments. 


\subsection{Travel agencies}

Travel agencies, whose main functions are the organisation, distribution and sale of tourist services and activities, see tourist rental housing as a new product that can be marketed, especially in the case of online agencies (OTA). Large international OTAs such as Expedia or Booking have fully integrated them into their product portfolios and offer the possibility of staying in tourist rental housing (Transparent Media Consulting, 2018); while various Spanish OTAs such as Destinia, eDreams or Rumbo have reached agreements with platforms such as HomeAway to offer their properties and thus be able to compete with Airbnb, the collaborative platform that dominates the Spanish tourist rental housing market. residents of areas where there is an abundance of tourist housing are one of the sectors most affected by the advent of this phenomenon. These are the residents of the historical centres and their surrounding neighbourhoods, where the bulk of the city's cultural heritage is usually located and which have the greatest official status and social recognition, as well as being the area most sought after by users of tourist rental housing.

For their part, the large Spanish offline travel agencies such as Viajes El Corte Inglés, Viajes Barceló, Nautalia and Halcón Viajes have expressed interest in including this product in their catalogues, and consequently are demanding policies and measures that allow for professional management and marketing of this type of accommodation, offering maximum guarantees for consumers. To this end, they are asking the authorities to establish a classification of the properties according to categories or types based on objective quality standards; and the owners to provide public and transparent information on tariffs, real time availability of accommodation and cancellation policies (LaComunity, 2018).

The other bone of contention for travel agencies is that of their equal tax treatment with peer-to-peer platforms, since the latter rely on fiscal offshoring strategies to reduce tax payments, despite the large profits they obtain as a result of their work as intermediaries between homeowners and clients (Hinojosa, 2014). This circumstance, together with the requirement of significant financial guarantees for agencies to operate, leads in practice to a clear disadvantage (sometimes described as unfair competition) that causes agencies to demand "that all companies should play by the same rules" (Brunat, 2017).

In any event, the demands of travel agencies are not being actively addressed by the authorities or homeowners, due to the secondary role they play in relation to this phenomenon and the absence of real pressure from the sector, either at the legal level or in the media.

\subsection{Political actors}

Political actors are important players in the scenario created by the boom in the tourist rental housing business, both on its ideological front (political parties) and in its executive phase (those responsible for policy and the decision-making process). As with other issues, political actors have taken divergent positions on the phenomenon, promoting, broadly speaking, two types of antagonistic actions:

- Those that support its expansion through neoliberal measures that favour free markets and free competition over other issues. This position essentially coincides with the interests of the owners of tourist homes, peer-to-peer digital platforms and the National Commission for Markets and Competition.
Players,
interests and
public
policies 
JTA

28.1
- Those that promote regulation, either to guarantee the "right to the city" of residents of overcrowded tourist areas, or to ensure a better balance between the different players competing in the tourist accommodation business. Both neighbourhood associations and hotel establishments and travel agencies agree on the need for public regulation.

The positioning of the political actors in power within the different geographical scopes under consideration (regional and local authorities) is clearly reflected in the regulations adopted in the planning of tourist rental housing. The wide variety of measures reveals the existence of various ideological patterns on the part of governments of different political persuasions (Tables 1 and 2).

Thus, at the regional level, we find governments that are in favour of growth in provision and in minimizing the legal requirements within their regions; and opposing them, more restrictive governments that give priority to the residential use of housing stock and that establish stricter requirements for the business and heavier sanctions for infractions (Table 1). It can therefore be deduced that the repercussions of the regulation of tourist rental housing on the different players involved depends to a large extent on the region where the housing is located and on the ideological positioning of its government.

Political differences can also be found between regional and municipal governments, which result in differences in the treatment of the phenomenon. Consequently, in many cases, local councils have opted to make use of urban planning instruments (general plans, special plans and municipal by-laws) to condition or restrict the tourist use of dwellings, further contributing to the complexity and diversity of the regulatory treatment of the phenomenon (Table 2).

If we compare both levels of government (municipal and regional) and their creation of regulations in relation to dwellings for tourist use, we can see how municipal instruments address social and environmental issues such as safeguarding the residential use of the dwellings, the right to rest of the residents or the protection of the urban environment (Table 2); whilst regional measures almost completely abstain from addressing these issues, basically limiting themselves to regulating technical or administrative aspects (Table 1).

\section{Discussion and conclusions}

This work has addressed the general scenario arising from the commencement and expansion of tourist rental housing in Spanish cities in the period 2010-2019. The study is based on the premise that the phenomenon occurs within the context of the transition from Fordism to post-Fordism in the tourist industry, which is strongly supported by the development of the digital economy and the proliferation of new businesses oriented to satisfy tourists' demands for new products and experiences. Within this general context, tourist accommodation is one of the clearest expressions of the change in model mentioned, insofar as it represents not only a new form of accommodation, but also that its development has triggered a whole network of companies providing innovative services within the so-called creative economy, in addition to boosting ancillary tourist industries.

The research has analysed the complex, variable scenario of multiple conflicts generated by tourist rental housing, and applies the stakeholders' theory, which focuses on the arguments, demands and strategies of the different players involved in the phenomenon. The fact is that the irruption of this new form of tourist accommodation has not only expanded the provision of accommodation in cities, but has also generated growing unease both in traditional business sectors and among residents of the affected areas, who are demanding greater control and regulation. 
The former consider tourist housing as a threat and unfair competition; the latter denounce that this activity directly affects the housing market, transforming it into a tourist commodity, which negatively impacts traditional neighbourhoods. In this context, public authorities are acting with initiatives of different kinds, either supporting the development of the phenomenon through liberalizing measures, or adopting regulatory instruments.

The study reveals that the heterogeneous treatment given to tourist rental housing by the various regulatory measures adopted to date is due to the different ideological positioning in relation to the phenomenon by governments of different political persuasions. Technical and legal arguments are used to justify these public policies. Likewise, we have seen that the aspects regulated by the authorities vary depending on their geographical scope. In this sense, we have ascertained that municipal governments mainly focus their regulation on social and environmental problems, while regional measures usually deal with administrative and technical aspects. This shows a considerable divergence in the regulation of tourist rental housing by different regions and cities. A heterogeneity that generates ill feeling in the sectors involved, who demand nationwide uniformity of criteria.

The research has also ascertained the close relationship between the tourist industry and the real estate business. The proliferation of tourist rental housing has led to the repurposing of a growing part of the housing stock towards holiday rentals, especially in the centres and the most attractive neighbourhoods of cities. This phenomenon has led to the emergence of small local owners offering their homes for this type of accommodation, while at the same time large investors and specialised companies have entered the sector, attracted by the high profitability of the activity, and have acquired many properties for tourist rental use.

This trend shows that, under the guise of collaborative economy, which allegedly encourages the coming together of small local entrepreneurs and tourists, this activity constitutes a lucrative business that, as such, should be subject to comprehensive management that guarantees the rights and obligations of all the players involved. This has not been the case in Spain, in view of the shortcomings detected in many of the regulations adopted on the subject and the complaints made by different sectors.

In short, the tourist rental housing scenario in Spain during the period under analysis has been characterised by the existence of conflict and tension between players, which has not been adequately resolved by the regulatory instruments adopted by the authorities. A panorama in which a clear distinction is made between the agents driving the activity: those who are opposed to or have little interest in regulating it (property owners and intermediary platforms) and the agents reacting to the phenomenon and demanding greater control of the activity and its negative impacts (mainly residents and hotel companies). This interplay of driving forces requires public authorities to guarantee greater balance, in order to ensure the sustainability of all aspects of urban tourist destinations.

To conclude, we consider that this work provides an understanding of the players, their interests and their interactions, which may be useful for proper planning, management and regulation of dwellings used for tourist accommodation which fosters better integration of the activity in the areas and neighbourhoods where it has become established. Likewise, the results of the article may be useful for research, since they allow an in-depth understanding of specific aspects of the phenomenon. 
JTA

28.1

\section{References}

Alba Sud (2018), "Manifiesto fundacional de la red SET de ciudades del Sur de Europa ante la Turistización". Available in http://www.albasud.org/noticia/es/1027/manifiesto-fundacional-de-lared-set-de-ciudades-del-sur-de-europa-ante-la-turistizaci-n (Accessed febrero 2019).

Alfonso, R. (2016), "Economía colaborativa: un nuevo mercado para la economía social". CIRIECEspaña, revista de economía pública, social y cooperativa, vol. 88, pp. 230-258.

Agencia Tributaria (2018), "La tributación de los alquileres turísticos". Available in https://www.agenciatributaria.es/AEAT.internet/Inicio/_componentes_/_Le_interesa_conocer/Hist orico/La_tributacion_de_los_alquileres_turisticos.shtml-_Accessed enero 2019).

Bakker, M., and Twining-Ward, L. (2018), Tourism and the sharing economy: policy and potential of sustainable peer-to-peer accommodation. World Bank.

Bani, S. (2017), "Las guías de vecindarios de Airbnb: El discurso turístico en la economía colaborativa". Círculo De Lingüística Aplicada a La Comunicación, vol. 72, pp. 15-28.

Blanco-Romero et al. (2017), "Claves de la reestructuración turística de la ciudad". En Naturaleza, territorio y ciudad en un mundo global. Actas del XXV Congreso de la Asociación de Geógrafos Españoles, AGE, pp. 1516-1524.

Bramwell, B. (2011). "Governance, the state and sustainable tourism: a political economy approach". Journal of Sustainable Tourism, 19 (4-5), 459-477.

Brunat, D. (2017), "Las agencias de viajes (Halcón, Barceló) van a por Airbnb: 'Queremos ofertar pisos en 2018'". Diario digital El Confidencial. Available in https://www.elconfidencial.com/empresas/2017-09-08/pisos-turisticos-airbnb-agencias-deviajes_1440133/ (Accessed marzo de 2019).

Cañada, E. and Murray, I. (2019), “Introducción: perspectivas críticas en turismo”. Turistificación global. Perspectivas críticas en turismo. Icaria, Barcelona, pp. 7-34.

Cócola-Gant, A. (2016), “Alojamiento turístico y desplazamiento de población”. Congreso Internacional Contested-Cities. Madrid 2016, vol. 163504, pp. 1-15.

Cuscó, E. and Font, J. (2015), "Nuevas formas de alojamiento turístico: comercialización, localización y regulación de las 'viviendas de uso turístico' en Cataluña”. Biblio 3W, Revista Bibliográfica de Geografía y Ciencias Sociales, vol. XX, No. 1.134.

De la Encarnación, A. (2016), "El alojamiento colaborativo: Viviendas de uso turístico y plataformas virtuales". Revista de Estudios de la Administración Local y Autonómica, No. 5. https://doi.org/10.24965/reala.v0i5.10350

Del Busto et al. (2019), "Marco normativo de los apartamentos y viviendas de uso turístico en España". Journal of Tourism Analysis: Revista de Análisis Turístico, vol. 26, No. 1, pp. 62-92. https://doi.org/10.1108/JTA-05-2018-0015

Delgado, M. (1998), “La Globalización ¿Nuevo Orden o Crisis del Viejo?”. Desde el Sur: Cuadernos de Economía y Sociedad, No. 1, pp. 5-37.

Díaz, R. J. et al. (2014), “Airbnb como nuevo modelo de negocio disruptivo en la empresa turística: Un análisis de su potencial competitivo a partir de las opiniones de los usuarios". Actas del XVIII Congreso de la Asociación de Expertos Científicos en Turismo (AECIT). Benidorm.

Esade (2015): Estudio del Impacto Social y Económico de las Viviendas de Uso Turístico. D Available in https://es.slideshare.net/esther_garsan/estudio-esade-fevitur-impacto-social-y-econmico-viviendastursticas-espaa

Europa Press (25 de septiembre de 2018): "Facua reclama regular las plataformas intermediarias en el alquiler de pisos turísticos". Available in https://www.europapress.es/turismo/nacional/noticiafacua-reclama-regular-plataformas-intermediarias-alquiler-pisos-turisticos-20180925224616.html

Exceltur (2015), Alojamiento turístico en viviendas de alquiler: impactos y retos asociados. Available in https:/www.exceltur.org/wp-content/uploads/2015/06/Alojamiento-tur\%C3\%ADstico-en-

viviendas-de-alquiler-Impactos-y-retos-asociados.-Resumen-Ejecutivo.-Exceltur.pdf

Exceltur (2020), “Balance empresarial del año 2019 y perspectivas para el 2020”. Informe Perspectivasturísticas, No 71. Available in https://www.exceltur.org/perspectivas-turisticas/ (Accessed febrero 2020)

Fuentes-Lojo, A. (2018), "La regulación del negocio de los pisos turísticos en las comunidades de propietarios". Diario La Ley, (9234), vol. 1. 
Fuentes-Lojo et al. (2018), "Conflictos legales en torno a las viviendas de uso turístico: aspectos administrativos, urbanísticos, contencioso-administrativos, civiles y procesales". Wolters Kluwer. España, vol. 19.

Freeman, R. E. (1984), Strategic management: A stakeholder approach. Boston: Pitman.

Ginés, G. (2018), "España pone coto a las viviendas de uso turístico". ABC. Available in https://www.abc.es/economia/abci-espana-pone-coto-viviendas-turistico201805130124_noticia.html (Accessed enero 2019).

Gómez, D., and Martín, C. (2015), "La participación de los stakeholders en los destinos turísticos españoles: análisis de la situación actual". Aposta. Revista de Ciencias Sociales, 65, 151-174.

González, P.J. (2017), "La oferta de viviendas de uso turístico a través de plataformas colaborativas: reflexiones desde el derecho de la competencia desleal". Revista de Estudios Europeos, vol. 70, pp. 111-125.

Guillén, N.A. (2015), “La vivienda de uso turístico y su incidencia en el panorama normativo español”. Revista Aragonesa de Administración Pública, vol. 45, pp. 101-144.

Guttentag, D. (2013), "Airbnb: disruptive innovation and the rise of an informal tourism accommodation sector”. Current Issues in Tourism, vol. 18, No. 12, pp. 1192-1217.

Harvey, D. (2008), “El derecho a la ciudad”. New left review, No. 53, pp. 23-39.

Hernández-Ramírez, J. (2018). "La voracidad del turismo y el derecho a la ciudad”.

Revista Andaluza de Antropología, No. 15, pp. 22-46.

Herrero, C. (2017), "Las viviendas de uso turístico: ¿el enemigo a abatir? Reflexiones sobre la normativa autonómica en materia de alojamientos turísticos". Revista de Estudios Europeos, No. 70, pp. 147-158.

Hiernaux, D. y González, C.I. (2014), “Turismo y gentrificación: pistas teóricas sobre una articulación”. Revista de Geografía Norte Grande, No. 58, pp. 55-70.

Hinojosa, V. (2014), "Los retos de la regulación del P2P”. Hosteltur. Available in https://www.hosteltur.com/187980_retos-regulacion-p2p.html (Accessed january 2019).

Instituto Multidisciplinar de la Empresa (2019): VI Barómetro del alquiler vacacional en España 2019. Universidad de Salamanca y Available in https://resources.homeaway.es/info/files

Ioannides, D. and Debbage, K. (1997), "Post-Fordism and flexibility: the travel industry polyglot”. Tourism Management, vol. 18 No. 4, pp. 229-241. https://doi.org/10.1016/ S0261-5177(97)00019-8

Jamal, T. y Getz, D. (1995), “Collaboration theory and community tourism planning”. Annals of Tourism Research, 22 (1), 186-204.

Jover, J. et al. (2018), Turistización y movimientos urbanos de resistencia: experiencias desde Sevilla. Milano, C. y Mansilla, J. A. (Coords.) Ciudad de vacaciones. Conflictos urbanos en espacios turísticos. Pol·len Edicions. Barcelona, pp. 403-438.

Judd, D.R. (2003), “El turismo urbano y la geografía de la ciudad”. Eure, vol. 87, No. 29, pp. 51-62.

LaComunity (2018). Obstáculos del alquiler vacacional para las agencias de viajes.

Hosteltur. Available in https://www.hosteltur.com/126732_obstaculos-alquiler-vacacionalagencias-viajes.html (Accessed febrero 2019).

Lash, S. y Urry, J. (1987), The end of organized capitalism. Polity. Cambridge.

Leal, J.L. and Martínez, A. (2017), "Tendencias recientes de la política de vivienda en España". Cuadernos de Relaciones Laborales, vol. 35, No. 1, p. 15.

Liu, Z. (2003), "Sustainable tourism development: A critique". Journal of Sustainable Tourism, 11 (6), 459-475. 
Martos, E. (2018), “Airbnb dejará de anunciar pisos turísticos de Sevilla que no estén registrados en la

Milano, C. and Mansilla, J.A. (Coords.) (2018), Ciudad de vacaciones. Conflictos urbanos en espacios turísticos. Pol·len Edicions. Barcelona.

Miralles, P. and Villar, A. (2016), "Las viviendas de uso turístico: un análisis del conflicto". International Journal of World of Tourism, vol. 6, No. 3, pp. 22-35.

Moreno-Izquierdo, L. et al. (2016), "Turismo colaborativo: ¿Está Airbnb transformando el sector del alojamiento?” Economistas, No. 150, pp. 107-119.

Muñoz, P.A. et al. (2019), "VI Barómetro del Alquiler Vacacional en España 2019". Universidad de Salamanca para Homeway. Available in https://csvcus.homeaway.com/rsrcs/static-pages/ master-477/vrbo/files/live/sites/vrbo/files/eses/shared/HomeAwayLab/pdf/VI BAROMETRO ALQUILER VACACIONAL ESPANA2019. pdf? $\mathrm{ga}=2.204033683 .2043569726 .1587460015-436261017.1587460015$ OCU (1,0 de abril de 2019): "OCU rechaza las normativas sobre alquiler turístico aprobadas en
Madritps://www.ocu.org/organizacion/prensa/
notas-de- Available prensa/2019/alquilerturistico100419

Oskam, J. and Boswijk, A. (2016), “Airbnb: the future of networked hospitality businesses". Journal of Tourism Futures, No. 2, vol. 1, pp. 22-42.

Presenza, A., and Cipollina, M. (2010), "Analysing tourism stakeholders networks". Tourism Review, 65(4), 17-30. https://doi.org/10.1108/16605371011093845

Quaglieri, A. and Russo. A.P. (2010), "Paisajes urbanos en la época post-turística. Propuesta de un marco analítico". Scripta Nova. Revista Electrónica de Geografía y Ciencias Sociales. vol. XIV, No. 323.

Recio, M.A. (2016) “Aproximación a la tributación del llamado turismo 2.0 en España, en especial las viviendas de uso turistico". International Journal of Scientific Management and Tourism, vol. 4, No. 2, pp. 207-225.

Richards, G. (2016), “El turismo y la ciudad ¿Hacia nuevos modelos?” Cidob d'afers internacionals, No. 113, pp. 71-87.

Richards, G. (2017), "El consumo de turismo en la posmodernidad o en la modernidad líquida". Oikonomics, No. 7, pp. 5-11.

Richards, G. (2018), "Tourism, an Underestimated Driving Force for the Creative Economy". RevistaTurismo em Análise, 29(3): 387-395.

Roca, M.A. (2017), “'Matando a la gallina de los huevos de oro?: Algunos apuntes sobre la nueva regulación de las viviendas de uso turístico (Especial referencia al caso andaluz)". Ridetur, vol. 2, No. 1, pp. 1-23.

Rodríguez-Alonso, R. (2011), "La política de vivienda en España en el contexto europeo. Deudas y retos". Boletín CF+S, vol. 47/48, pp. 125-172.

Román, A. (2018), Planificación urbanística del turismo: la regulación de las viviendas de uso turístico en Madrid y Barcelona. Revista de Estudios de la Administración Local y Autonómica.

Sánchez-Uzábal, A. and Rey-Mazón, P. (2019), "Informe Efecto Airbnb en la ciudad de Valencia”. Cátedra en Economía Colaborativa y Transformación Digital. Universidad de Valencia. Available in https://www.uv.es/uvweb/nullca/arees-investigacio/vivenda/informe-efecto-airbnbciudad-valencia-1286072510425.html (Accessed septiembre 2019).

Santos-Pavón, E.L. and Fernández-Tabales, A. (2010), "El litoral turístico español en la encrucijada: entre la renovación y el continuismo". Cuadernos De Turismo, vol. 25, pp. 185-206.

Sautter, E.T. and Leisen, B. (1999), "Managing stakeholders a Tourism Planning Model". Annals of Tourism Research, 26 (2), 312-328. 
Transparent Media Consulting, (2018), Airbnb ya no es el líder en la distribución de alquiler turístico. Tourinews. Available in https://www.tourinews.es/resumen-de-prensa/notas-de-prensaempresas-turismo/airbnb-ya-no-es-el-lider-en-la-distribucion-de-alquiler-turistico_4451067_102.html (Accessed enero 2019).

Urry, J. (1999), "Sensing the City". Judd, D. y Fainstein, S. (editors). The tourist city. Yale University Press. London, pp. 71-88.

Vargas, R.L. (2019) Una de cada cuatro viviendas de uso turístico es clandestina. La Razón. Available in https:/www.larazon.es/economia/una-de-cada-cuatro-viviendas-de-uso-turistico-esclandestina-CG24772132/ (Accessed octubre 2019).

\section{Players, \\ interests and \\ public \\ policies}

Wang, N. (1999), "Rethinking authenticity in tourism experience". Annals of Tourism Research, vol. 2, No. 26, pp. 349-370.

National and regional legislation

Ley 29/1994, de 24 de noviembre, de arrendamientos urbanos.

Ley $4 / 2013$, de 4 de junio, de medidas de flexibilización y fomento del mercado del alquiler de vivienda.

Ley 6/2017, de 31 de julio, de modificación de la Ley 8/2012, de 19 de julio, del turismo de las Illes Balears.

Ley 15/2018, 7 de junio, de turismo, ocio y hospitalidad de la Comunidad Valenciana.

Real Decreto 1070/17, de 29 de diciembre, de regulación de plataformas digitales y viviendas de uso turístico.

Real Decreto-ley 7/2019, de 1 de marzo, de medidas urgentes en materia de vivienda y alquiler.

Decreto foral 230/2011, de 26 de octubre, de ordenación de los apartamentos turísticos en la Comunidad Foral de Navarra.

Decreto 182/2012, de 7 de septiembre, de ordenación y clasificación de los apartamentos turísticos de la Comunidad Autónoma de Extremadura.

Decreto 159/2012, de 20 de noviembre, de establecimientos de alojamiento turístico y de viviendas de uso turístico de Cataluña.

Decreto 80/2015, de 5 de mayo, de viviendas de uso turístico de Aragón.

Decreto 113/2015, de 22 de mayo, de viviendas vacacionales de la Comunidad Autónoma de Canarias.

Decreto 28/2016, de 2 de febrero, de viviendas con fines turísticos y de modificación del Decreto 194/2010, de 20 de abril, de establecimientos de apartamentos turísticos de Andalucía.

Decreto 48/2016, de 10 de agosto, de viviendas vacacionales y viviendas de uso turístico del Principado de Asturias.

Decreto 12/2017, de 26 de enero, de apartamentos turísticos, viviendas turísticas y viviendas de uso turístico de Galicia.

Decreto 3/2017, de 16 de febrero, de establecimientos de alojamiento en la modalidad de vivienda de uso turístico de Castilla y León.

Decreto 36/2018, de 29 de mayo, de ordenación de los apartamentos turísticos y las viviendas de uso turístico en Castilla-La Mancha. 